\title{
KAJIAN APLIKASI STANDAR:TATA CARA PERENCANAAN STRUKTUR BETON UNTUK BANGUNAN GEDUNG DALAM PELAKSANAAN BANGUNAN DI INDONESIA
}

\author{
Silvia F Herina
}

\begin{abstract}
Concrete is a widely used material for building system, new developments in its technology are being grown more and more. With the enormously vary of design, construction methods, and materials used also to guarantee the building safety, concrete regulation should be coordinated. Indonesian concrete regulation established in 1971, development of high technologies in foreign countries and Indonesia were motivated Indonesian concrete expert to revise that standard. In 1992 the new modern Indonesian concrete standard published. Hence it was revised again in 2002. The existing of standard is not guarantee that it will applied in all building design, the appropriate socialization is needed. Through the research's year 2006 of Research Institute of Human Settlements, Public Work Department, study on concrete standards application in building construction was carry out. Respondents were taken from representative's area of the entire of Indonesia. Mostly of respondents was understood much on the important of standards application, however nearly 30\% of public's respondents, 4\% university's, and 7\% private and public consultants have not applied the new concrete standard in their construction design yet. The most part of new standard were need commentaries. The paper also proposed decision system of standard's socialization material, based on survey's result.
\end{abstract}

Key words: standard, concrete, building construction

\section{PENDAHULUAN}

Sebagai material yang sangat banyak digunakan, beton mendapat tempat khusus dalam dunia konstruksi, perkembangan inovasi teknologinya pun berjalan sangat cepat. Di dunia internasional sudah sejak lama ada kesepakatan dalam menyeragamkan peraturan yang menyangkut teknologi beton. Pada tahun 1953 CIB (Conseil International du Batiment) menetapkan prinsip-prinsip dasar perencanaan campuran matrik beton dan konstruksi penulangannya yang kemudian dilengkapi oleh CEB (Comite' Europe'en du Beton) pada tahun 1964, dan dilanjutkan oleh ISO (International Standardization Organization).

Di Indonesia, peraturan beton Indonesia mulai dikenalkan pada tahun 1955, namun pemakaiannya masih sangat terbatas, pedoman konstruksi beton Indonesia yang disusun oleh Ir. Sutami (Menteri Pekerjaan Umum saat itu) berhasil diterbitkan oleh Badan Penerbit Pekerjaan Umum tahun 1966, namun pengunaannya juga masih terbatas di lingkungan pekerjaan umum. Peraturan yang lebih baru dan modern, selesai disusun para ahli konstruksi Indonesia pada tahun 1971 yang dikenal dengan nama:Peraturan Beton Bertulang Indonesia, PBI 1971, peraturan ini mengacu pada aturan FIP$\mathrm{CEB}$, dan ACl (American Concrete Institute) 31870 , serta ada beberapa bagian dari Unified British Standard 1970, meski mengacu pada standar internasional, sebenarnya berbagai ketentuan dalam peraturan ini sudah disesuaikan sedapat mungkin sesuai dengan kondisi di Indonesia.

Dengan makin majunya standar-standar acuan, berkembangnya teknologi dan penggunaan bahan baru, dan juga permasalahan karena kondisi alam dan lingkungan, para ahli beton sepakat untuk memperbaharui PBI 1971, ditandai dengan dikeluarkannya Tata Cara Penghitungan Struktur Beton untuk Bangunan Gedung, SNI 03-2847-1992, yang secara total mengacu pada $\mathrm{ACl} 318-86$, pada tahun 2002 standar ini telah diperbaharui kembali dengan banyak penyesuaian pada kondisi dan perkembangan teknologi terbaru di Indonesia, dan berjudul:Tata cara perencanaan struktur beton untuk bangunan gedung (TCPSBUBG)

Struktur beton adalah salah satu struktur yang berkembang terus dengan selalu adanya inovasi material matrik dan teknik konstruksi baru yang makin memperhitungkan standar keamanan lebih tinggi .

Ketersediaan standar yang mendukung pengembangan tersebut tentu saja sangat membantu para perencana maupun pelaksana bangunan, yang menjadi persoalan adalah pada kenyataannya kecepatan pemahaman akan standar teknis yang baru muncul tidak sama pada setiap pemangku kepentingan, khususnya pada standar beton Indonesia ini beberapa perencana maupun pihak akademis di daerah masih menggunakan PBI 1971, atau bahkan standar yang lebih lama, tidak akan menjadi masalah jika lokasi dimana bangunan yang direncanakan dengan standar lama cukup stabil, aman terhadap gempa, namun keamanan 
bangunan akan sangat menurun jika kebetulan misalnya bangunan ada di zona gempa cukup tinggi. Beberapa hal yang patut dipertimbangkan antaranya adalah posisi Indonesia yang ada di daerah rawan bencana gempa tinggi, karenanya sangat penting perencanaan bangunan mengacu pada standar baru yang sudah lebih mempertimbangkan gaya gempa ini. Pemakaian material baru yang sekarang sangat marak, yang dikenal dengan beton komposit, juga mulai di atur dalam standar beton yang terakhir.

Hal berikutnya yang sering terjadi adalah, ketersediaan standar yang tidak didampingi dengan ketepatan sosialisasinya, standar hanya dikenal oleh lingkungan terbatas yang kebetulan berminat dan punya kesempatan untuk memperolehnya, sedangkan masyarakat luas pengguna belum banyak yang mengenal dan memahaminya.

Dengan maksud memperoleh pendekatan yang paling tepat untuk lebih mesosialisasikan standar beton tersebut, melalui kegiatan penelitian Pusat Litbang Permukiman tahun 2006, dilakukan kajian aplikasi SNI TCPSBUBG dengan menggunakan parameter utama perubahan atau penambahan ketentuan dalam standar terbaru. Dalam paper ini disampaikan hasil kajian dan evaluasi yang diambil secara acak di daerah-daerah yang dianggap mewakili di seluruh bagian Indonesia.

\section{PERKEMBANGAN PRINSIP STANDAR PENGHITUNGAN STRUKTUR BETON INDONESIA}

Dapat dikatakan sampai saat ini standar beton Indonesia mengalami dua tahapan perubahan prinsip dasar perencanaan yang berbeda, yakni Peraturan Beton Bertulang Indonesia 1971 yang prinsip perhitungan kekuatannya berdasarkan kekuatan batas, dan tata cara penghitungan struktur beton untuk bangunan gedung 1992 dan TCPSBUBG 2002, yang menggunakan metode beban terfaktor, disamping metode beban kerja yang dapat digunakan sebagai metode alternatif, khususnya pada penghitungan pemeriksaan kondisi layak.

Dari sisi perencanaan, salah satu keuntungan Tata cara penghitungan struktur beton dibandingkan dengan PBI 1971 adalah karena Tata cara tersebut mengacu pada standar gempa yang baru, dimana para perencana diberi peluang untuk dapat memilih sistem struktur dengan berbagai tingkat daktilitas (sesuai ketentuan dalam standar bangunan tahan gempa) yang diinginkan, pada Peraturan Beton Bertulang Indonesia 1971, perencana tidak mempunyai pilihan.
Pada tata cara penghitungan struktur beton untuk bangunan gedung 1992, dengan pertimbangan lebih praktis, ketentuan mengenai bahan beton dipisahkan dijadikan standar lain, jadi standar tersebut hanya berisi ketentuan mengenai struktur beton saja, tetapi dengan kesepakatan para ahli untuk sepenuhnya mengacu pada $\mathrm{ACl} 318$, pada revisinya TCPSBUBG-2002, ketentuan bahan digabungkan kembali dengan ketentuan struktur.

Ada beberapa lonjakan perbedaan ketentuan dari standar 1971 ke standar 1992/2002, contohnya ketentuan mengenai kuat tekan beton yang disyaratkan fc', yang digunakan dalam formulasi perencanaan diperoleh dari benda uji silinder, menggantikan kuat tekan beton rata-rata $\sigma$ 'bm yang didapat dari benda uji kubus, jika menggunakan benda uji silinder harus digunakan faktor pengali 0,83. Juga adanya ketentuanketentuan baru mengenai detail penulangan, diameter pembengkokan tulangan dan sebagainya yang sebelumnya belum ada dalam PBI 1971. Pemahaman ketentuan-ketentuan dasar tersebut merupakan salah satu kajian dalam studi ini.

\section{KAJIAN APLIKASI}

Kegiatan utama dari kajian ini adalah melakukan survey kuesioner yang diikuti oleh interview pada para pemangku kepentingan di bidang pelaksanaan bangunan: pengambil keputusan dari dinas Pekerjaan Umum propinsi dan kota, konsultan perencana BUMN atau swasta, dan dosen fakultas teknik sipil. Untuk mencapai tujuan kajian ini, survey kuesioner dibagi dalam tiga bagian yang berbeda, dan satu bagian tambahan mengenai konsesi hukum. Pembagiannya seperti dijelaskan berikut:

Yang pertama adalah survey tentang pemahaman manfaat diaplikasikannya standar dalam pelaksanaan bangunan didasarkan pada empat kriteria yang ditentukan, yakni:

- $\quad$ peningkatan produk elemen bangunan yang berkwalitas

- peningkatan kwalitas bangunan secara keseluruhan

- reduksi pekerjaan perbaikan yang tidak diperlukan

- peningkatan kenyamanan penghuni bangunan/peningkatan reputasi pemangku kepentingan

dengan mempertanyakan pendapat responden tentang: seberapa penting kriteria-kriteria di atas menunjang peningkatan kwalitas kehidupan masyarakat Indonesia dan apakah kriteria 
tersebut sudah termuat dalam SNI bidang bangunan.

Bagian kedua berisi survey pemahaman teknis yang didasarkan pada sudah mengaplikasikan secara penuh, sebagian, sebagian kecil atau belum sama sekali standar beton Indonesia: TCPSBUBG dalam perencanaan dan pelaksanaan bangunan.

Bagian yang ketiga adalah tentang tingkat kesulitan pemahaman materi akibat perkembangan standar beton lama ke TCPSBUBG, parameter survey yang diambil adalah ketentuan bahan beton, perencanaan pencampuran (concrete mix design), detail penulangan, parameter kekuatan, perencanaan dinding, pelat dan fondasi, beton pracetak, beton komposit, beton prategang, beton polos, dan bangunan eksisting.

Untuk permasalahan lainnya dalam upaya aplikasi seperti tidak adanya buku standar, pembengkakan biaya dengan diterapkannya standar baru, dan konsesi hukum, survey tidak dilakukan dengan sistem skala, tetapi berupa eksplanasi.

\section{HASIL KAJIAN}

\subsection{Karakteristik Responden}

Responden dari kalangan institusi publik, universitas, dan BUMN/konsultan dengan persentase $30 \%$, 45\%, dan $25 \%$. Hampir $65 \%$ responden mempunyai pengalaman dengan pelaksanaan bangunan tinggi (lebih dari 4 lantai) selama lebih dari delapan tahun. Kualifikasi responden tidak diklasifikasikan secara khusus, tetapi hampir semua responden terlibat di lapangan secara aktif. Responden diambil secara acak dari daerah yang dianggap mewakili seluruh Indonesia: Banda Aceh, Medan, Padang, Palembang, Batam, Banjarmasin, Menado, Ujung Pandang,
Denpasar, Mataram, Surabaya, Semarang, Bandung, dan Jakarta.

\subsection{Analisa Data}

Data dianalisa dengan menggunakan program trial SPSS 11.0: distribusi frekuensi sederhana dan pengaruh variabel, nilai variabel diambil (1) sampai dengan (4) untuk menyatakan tingkat pemahaman standar, tingkat telah mengaplikasikan SNI beton, dengan pengartian (1) nilai terendah dan (4) nilai tertinggi. Serta nilai variabel (1): terendah sampai dengan (5): tertinggi untuk tingkat pemahaman butir isi standar.

Nilai rata-rata diambil berdasar formula:

$$
x^{\prime}=\frac{\sum f i x x i}{\sum f i}
$$

$x_{i} \quad$ : nilai variabel

$f_{i} \quad$ : frekuensi nilai yang bersangkutan

Ringkasan pemahaman manfaat aplikasi SNI bidang bangunan dalam menunjang peningkatan kualitas kehidupan masyarakat Indonesia ditampilkan pada Tabel 1, sedangkan uraiannya dapat dilihat pada Tabel $6,7,8$, dan 9 .

Pemahaman akan keberadaan SNI bidang bangunan disampaikan dalam tabel 2 berikut, uraiannya dapat dilihat pada tabel 10 .

Tabel 3 menunjukkan hasil survey tingkat aplikasi SNI: TCPSBUBG, uraian keterangannya dapat dilihat pada Tabel 11, 12, dan 13. Perbedaan tingkat aplikasi di daerah Pulau Jawa dan di luar Pulau Jawa juga diupayakan dikaji, hasilnya dapat dilihat pada Tabel 4, dengan uraian pada Tabel 14 dan 15. Kadar pemahaman dan perlunya penjelasan lebih lanjut terhadap isi standar di presentasikan dalam Tabel 5 , berikut uraiannya pada Tabel 16 sampai Tabel 25.

Tabel 1 Tingkat Kepentingan Kriteria Manfaat Aplikasi Standar Bidang Bangunan dalam Menunjang Peningkatan Kualitas Kehidupan Masyarakat Indonesia

\begin{tabular}{|c|c|c|c|c|c|c|c|c|}
\hline \multirow{2}{*}{ No } & \multirow{2}{*}{ Kriteria Manfaat Aplikasi Standar } & \multicolumn{4}{|c|}{ Frekuensi } & \multirow{2}{*}{ Mean } & \multirow{2}{*}{ St.dev } & \multirow{2}{*}{ Skala } \\
\hline & & 1 & 2 & 3 & 4 & & & \\
\hline
\end{tabular}




\begin{tabular}{|c|l|c|c|c|c|c|c|c|}
\hline 1. & $\begin{array}{l}\text { Peningkatan produk elemen bangunan } \\
\text { yang berkualitas }\end{array}$ & - & 3 & 25 & 27 & 3.4364 & 0.6013 & 1. \\
\hline 2. & $\begin{array}{l}\text { Peningkatan kualitas bangunan } \\
\text { secarakeseluruhan }\end{array}$ & & - & 24 & 31 & 3.5636 & 0.5005 \\
\hline 3. & $\begin{array}{l}\text { Reduksi pekerjaan perbaikan yang tidak } \\
\text { diperlukan }\end{array}$ & - & - & 16 & 39 & 3.7091 & 0.4583 & $\begin{array}{l}\text { 2. } \\
\text { penting } \\
\text { tidak penting } \\
\text { penting } \\
\text { sangat penting }\end{array}$ \\
\hline 4. & $\begin{array}{l}\text { Peningkatan kenya-manan penghuni } \\
\text { bangunan }\end{array}$ & - & - & 24 & 31 & 3.5636 & 0.5005 & \\
\hline
\end{tabular}

Tabel 2 Tingkat Termuatnya Keempat Kriteria Manfaat Aplikasi Standar dalam SNI Bidang Bangunan

\begin{tabular}{|c|c|c|c|c|c|c|c|}
\hline \multirow{2}{*}{ Kriteria Manfaat Aplikasi Standar } & \multicolumn{4}{|c|}{ Frekuensi } & \multirow{2}{*}{ Mean } & \multirow{2}{*}{ St.dev } & \multirow{2}{*}{ Skala } \\
\hline & 1 & 2 & 3 & 4 & & & \\
\hline $\begin{array}{l}\text { - } \text { peningkatan produk elemen yang berkualitas } \\
\text { - peningkatan kualitas bangunan secara } \\
\text { keseluruhan } \\
\text { - reduksi pekerjaan yang tidak diperlukan } \\
\text { - peningkatan kenyamanan penghuni bangunan }\end{array}$ & 4 & 22 & 20 & 9 & 2.6182 & 0.8496 & $\begin{array}{l}\text { 1. tidak tahu } \\
\text { 2. belum termuat } \\
\text { 3. sebagian } \\
\text { termuat } \\
\text { 4. sudah semua } \\
\text { termuat }\end{array}$ \\
\hline
\end{tabular}

Tabel 3 Tingkat Aplikasi TCPSBUBG di Berbagai Instansi

\begin{tabular}{|c|c|c|c|c|c|c|c|c|}
\hline \multirow{2}{*}{ No } & \multirow{2}{*}{ Intansi } & \multicolumn{4}{|c|}{ Ffrekuensi } & \multirow{2}{*}{ Mean } & \multirow{2}{*}{ St.dev } & \multirow{2}{*}{ Skala } \\
\hline & & 1 & 2 & 3 & 4 & & & \\
\hline 1. & Publik & 6 & 5 & 1 & 2 & 1.9286 & 1.0716 & \multirow{3}{*}{$\begin{array}{ll}\text { 1. } & \text { sama sekali belum pernah } \\
\text { 2. } & \text { aplikasi standar lama } \\
\text { 3. } & \text { aplikasisebagian standar lama/se- } \\
\text { bagian TCPSBUBG } \\
\text { 4. }\end{array}$} \\
\hline 2. & Universitas & 1 & 3 & 5 & 16 & 3.4400 & 0.8698 & \\
\hline 3. & BUMN / konsultan & 1 & 3 & 4 & 6 & 3.0714 & 0.9972 & \\
\hline
\end{tabular}

Tabel 4 Tingkat Aplikasi TCPSBUBG di Pulau Jawa dan di Luar Pulau Jawa

\begin{tabular}{|c|c|c|c|c|c|c|c|c|}
\hline \multirow[b]{2}{*}{ No. } & \multirow{2}{*}{ Lokasi instansi } & \multicolumn{4}{|c|}{ Frekuensi } & \multirow[b]{2}{*}{ Mean } & \multirow[b]{2}{*}{ St.dev. } & \multirow[b]{2}{*}{ Skala } \\
\hline & & 1 & 2 & 3 & 4 & & & \\
\hline 1. & Dalam pulau Jawa & 6 & 9 & 11 & 22 & 3.0208 & 1.0815 & $\begin{array}{l}\text { 1. sama sekali belum pernah } \\
\text { 2. aplikasi standar lama } \\
\text { 3. aplikasi sebagian st.lama/ sebag. }\end{array}$ \\
\hline 2. & Di luar pulau Jawa & 2 & 3 & - & 6 & 2.6667 & 1.2535 & 4. sudah penuh aplikasi TCPSBUBG \\
\hline
\end{tabular}

Tabel 5 Usulan Penjelasan Lebih Lanjut dan Revisi yang diperlukan dari ketentuan dalam TCPSBUBG

\begin{tabular}{|c|c|c|c|c|c|c|c|c|c|c|}
\hline \multirow[b]{2}{*}{ No. } & \multirow[b]{2}{*}{ Topik } & \multicolumn{5}{|c|}{ frekuensi } & \multirow[b]{2}{*}{ Mean } & \multirow[b]{2}{*}{ St.dev } & & \multirow[b]{2}{*}{ Skala } \\
\hline & & 1 & 2 & 3 & 4 & 5 & & & & \\
\hline 1. & Ketentuan bahan & 2 & 3 & 7 & 14 & 19 & 4.0000 & 1.1281 & \multirow[t]{2}{*}{1.} & \multirow{2}{*}{$\begin{array}{l}\text { sangat } \\
\text { tidakpent }\end{array}$} \\
\hline 2. & Perencanaan campuran & 2 & 4 & 9 & 11 & 18 & 3.8864 & 1.1854 & & \\
\hline
\end{tabular}




\begin{tabular}{|c|c|c|c|c|c|c|c|c|c|}
\hline 3. & Detail penulangan & 2 & 3 & 9 & 9 & 24 & 4.0638 & 1.1685 & \multirow{8}{*}{\begin{tabular}{|ll} 
2. & tidak \\
3. & penting \\
3. & penting \\
4. & penting \\
5. & sangat \\
& penting
\end{tabular}} \\
\hline 4. & Parameter kekuatan & 2 & 4 & 8 & 15 & 12 & 3.7561 & 1.1353 & \\
\hline 5. & $\begin{array}{l}\text { Perencanaan dinding, pelat, } \\
\text { dan fondasi }\end{array}$ & 2 & 3 & 13 & 17 & 9 & 3.6364 & 1.0363 & \\
\hline 6. & Beton pracetak & 2 & 5 & 12 & 16 & 9 & 3.5682 & 1.0868 & \\
\hline 7. & Beton komposit & 2 & 2 & 16 & 14 & 9 & 3.6047 & 1.0267 & \\
\hline 8. & Beton prategang & 2 & 2 & 16 & 14 & 10 & 3.6364 & 1.0363 & \\
\hline 9. & Beton polos & 2 & 8 & 16 & 11 & 6 & 3.2558 & 1.0711 & \\
\hline 10. & Bangunan eksisting & 2 & 7 & 16 & 13 & 6 & 3.3182 & 1.0515 & \\
\hline
\end{tabular}

\subsection{Konsesi Hukum dan Permasalahan Lain}

Beberapa responden memberikan komentar setuju jika SNI ditekankan dalam kontrak pelaksanaan bangunan dengan detail untuk menjamin kualitas pekerjaan, karena adanya beberapa ketidak seragaman di lapangan, seperti mutu material, tingkat keahlian tenaga tukang dan ladennya, namun komentar terbanyak mengatakan bahwa penekanan SNI sebaiknya cukup sederhana saja, sehingga ada toleransi jika mengalami permasalahan di lapangan.

Beberapa responden juga memberikan komentar bahwa tidak mengaplikasikan TCPSBUBG karena belum tahu keberadaannya, kesulitan memperoleh buku SNInya, dan kalau tersedia masih tidak faham isinya atau jika digunakan, membuat biaya konstruksi menjadi lebih mahal.

\section{DISKUSI}

Pada umumnya pemahaman pemangku kepentingan pelaksanaan bangunan mengenai pentingnya standar sudah cukup tinggi, hal ini dapat dilihat dari Tabel 1, rata-rata menyatakan aplikasi standar dapat menunjang peningkatan kualitas kehidupan masyarakat Indonesia melalui peningkatan kualitas bangunan, berkurangnya pekerjaan perbaikan yang tidak diperlukan, juga peningkatan kenyamanan bangunan.

Diketahuinya keberadaan standar bidang bangunan oleh responden dapat dilihat pada Tabel 2, rata-rata dapat mengeluarkan kesimpulan bahwa kriteria aplikasi standar di atas baru sebagian termuat dalam SNI.

Survey tentang diaplikasikannya TCPSBUBG memperoleh hasil bahwa instansi publik terutama di daerah sebagian besar masih menggunakan standar beton yang lama, sedangkan di universitas dan BUMN/konsultan sebagian sudah menerapkan standar TCPSBUBG. Kemungkinan besar hal ini disebabkan karena rata-rata responden dari universitas adalah dosen yang mempunyai minat dan aktif mengikuti perkembangan dunia konstruksi. Responden dari BUMN/konsultan meski berada di daerah, rata-rata kendali perencanaan ada di Jakarta (dimana pengaturan mengenai standar sudah dijalankan sangat ketat), jika di daerah masih menggunakan standar yang lama, boleh jadi karena dalam peraturan daerahnya belum diatur ketentuan mengenai standar-standar yang baru.

Tidak ada perbedaan yang signifikan dari tingkat aplikasi standar di Pulau Jawa dan di luar Pulau Jawa, beberapa responden dari universitas di luar Pulau Jawa memberikan respon pengetahuan yang baik terhadap standar-standar konstruksi.

Dari 10 topik utama isi TCPSBUBG yang dipilih, hampir semua responden menyatakan perlunya diberikan penjelasan lebih lanjut, dan beberapa diantaranya memerlukan revisi yang disesuaikan dengan kondisi saat ini.

Tingkat komprehensif sebuah perjanjian konsesi dipengaruhi oleh tingkat komprehensif kerangka hukum yang ada, dimana semakin komprehensif kerangka hukum yang ada semakin sederhana perjanjian konsesi karena sebagian isinya sudah merujuk ke standar/peraturan yang ada. Memasukkan secara detail ketentuan standar diinginkan oleh beberapa responden, tetapi sebagian menginginkan agar tetap ada toleransi dalam pelaksanaan di lapangan, jadi ketentuan standar dimasukkan secara sederhana saja.

Kesulitan umum yang selalu terjadi dalam masalah belum mengaplikasikan standar adalah karena tidak tahu keberadaannya, kesulitan mem-peroleh buku SNI, dan karena belum memahami isinya, atau berpendapat bahwa dengan penerapan standar biaya konstruksi akan jauh lebih mahal.

\section{KESIMPULAN}

Hampir semua pemangku kepentingan dalam pelaksanaan bangunan memahami tentang 
manfaat standar dalam meningkatkan mutu konstruksi. Belum mengaplikasikan suatu standar adalah karena tidak tahu keberadaannya atau kesulitan cara memperolehnya.

Tata cara perencanaan struktur beton untuk bangunan gedung dianggap dapat digunakan sebagai acuan dalam perencanaan konstruksi, namun diperlukan suatu "jembatan antara" yang mungkin dapat berupa manual-manual yang bisa digunakan untuk memberikan penjelasan perubahan ketentuan-ketentuan yang ada dari ketentuan dalam standar beton yang lama.

Peningkatan Sumber Daya Manusia sangat penting dalam upaya serta kecepatan pemahaman suatu standar, makin lanjut pendidikan atau makin banyak pengalaman dalam pelaksanaan lapangan seseorang akan makin mudah dalam memahami standar.

Diperlukan pelaksanaan suatu payung hukum (Undang-Undang Bangunan Gedung, misalnya) sehingga standar dapat diberlakukan secara wajib dan mengikat.

Keberadaan standar TCPSBUBG harus didampingi dengan cara sosialisasinya yang tepat, hasil kajian menunjukkan sosialisasi sebaiknya yang utama dititik beratkan pada instansi publik di daerah, kemudian BUMN dan pihak universitas.

\section{SARAN}

Berdasarkan hasil kajian, penentuan materi sosialisasi TCPSBUBG hendaknya dilakukan dengan sistem aktif, bagan alir nya sebagai pada Gambar 1.

Selain pengetahuan dasar partisipan, variabel material sosialisasi harus melibatkan: perilaku/kinerja, komitmen, kualitas, dan edukasi partisipan (didapat dari kuesioner yang harus diisi partisipan sebelum sosialisasi dilaksanakan). Pada saat sosialisasi berlang-sung variabel material bergerak aktif dengan mempertimbangkan koreksi yang timbul sebagai reaksi partisipan.

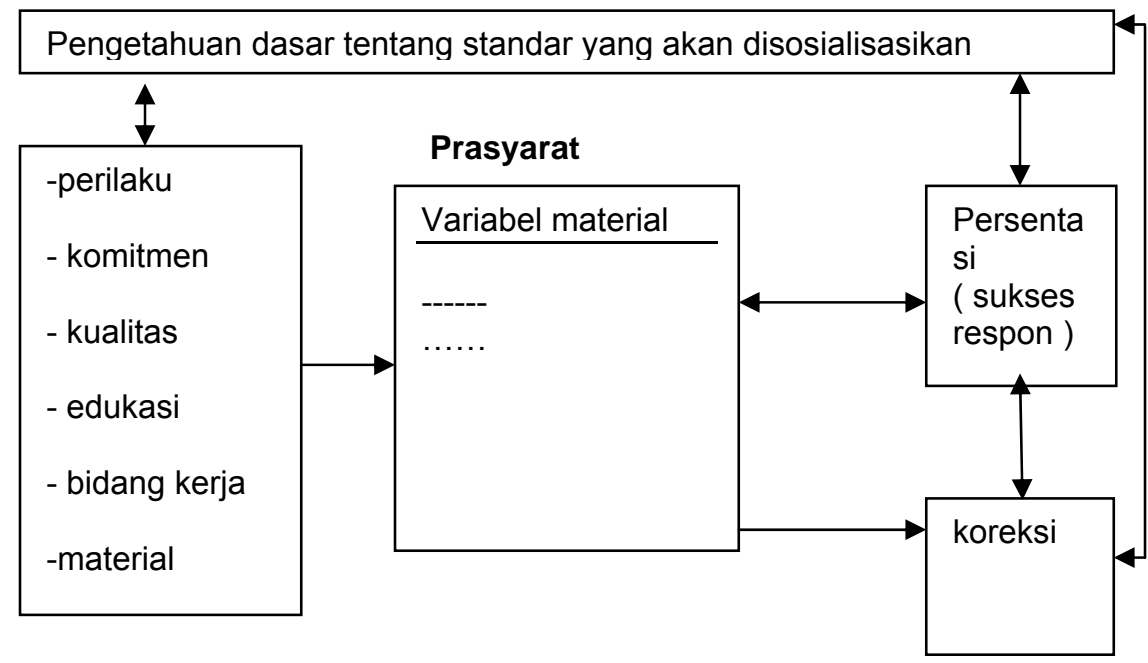

Gambar 1 Bagan Penentuan Materi Sosialisasi Standar

\section{DAFTAR ISI}

1. N.I. - 2. 1971, Peraturan Beton Bertulang Indonesia, Departemen Pekerjaan Umum dan Tenaga Listrik, Direktorat Jenderal Cipta Karya, Lembaga Penyelidikan Masalah Bangunan

2. SNI 03-2847-1992, Tata Cara Penghitungan Struktur Beton Untuk Bangunan Gedung ", Departemen Pekerjaan Umum, Yayasan Lembaga Penyelidikan Masalah Bangunan
3. SNI 03-2847-2002, Tata Cara Perencanaan Struktur Beton untuk Bangunan Gedung, Badan Standarisasi Nasional

4. Suprapto, Dr. Ir, MSc, et al. 2006. Aplikasi NSPM dalam Pembangunan Infrastruktur Perumahan dan permukiman, Pusat Litbang Permukiman, Badan Litbang Departemen Pekerjaan Umum

5. Sutami, Ir, 1971. Konstruksi Beton Indonesia. Badan Penerbit Pekerjaan Umum 


\section{BIODATA}

Silvia. F. Herina, Peneliti di bidang Rekayasa Teknik Sipil, Pusat Litbang Permukiman, Sarjana
Teknik Sipil dari Unika Parahyangan, 1985, Post Graduate Development Technologies on Civil Engineering, Melbourne University, 1991, Magister Manajemen dan Rekayasa Konstruksi. 